\title{
Protecting Water Resources from Agricultural Pesticides ${ }^{1}$
}

O. Norman Nesheim and Frederick M. Fishel ${ }^{2}$

This publication describes practices that help protect groundwater and surface water from pesticide contamination.

\section{Summary}

Because cleanup of water contaminated with one or more pesticides is complicated, time-consuming, expensive and usually not feasible, prevention is the best solution for water pollution. The following management practices will help to retain pesticides in target areas and keep pesticides out of water resources.

\section{Consider the Vulnerability of the Site}

Determine the susceptibility of the soil to leaching. Soil texture, organic-matter content, soil moisture and permeability all affect pesticide movement. Some pesticides readily move through soils that are well drained, sandy, or low in organic matter (Figure 1).

For example, many of the common soils used for citrus production in Florida have a content of well over $90 \%$ sand.

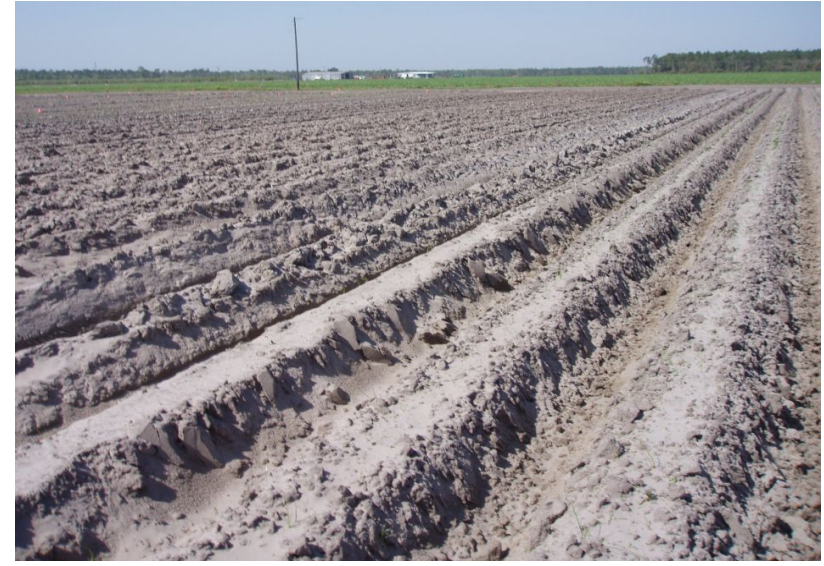

Figure 1. Many of Florida's agricultural soils are well drained, high in sand and low in organic matter. Credits: F.M. Fishel, UF/IFAS PIO.

Determine, to the extent possible, the depth of the water table and the relative permeability of the geologic layers between the soil surface and the groundwater. If sinkholes are present, surface-water runoff can quickly reach groundwater with little natural soil filtering. The slope of the field and the relative location of lakes, ponds, streams, canals, or wetlands to the application site also determine the vulnerability of these surface-water bodies to contamination from pesticides.

1. This document is PI1, one of a series of the Agronomy Department, Florida Cooperative Extension Service, Institute of Food and Agricultural Sciences, University of Florida. Original publication date, June 1993. Revised April 2009. Visit the EDIS Web site at http://edis.ifas.ufl.edu.

2. O. Norman Nesheim, formerly professor and pesticide information coordinator, Food Science and Human Nutrition Department, and Frederick M. Fishel, associate professor, Agronomy Department, and director, Pesticide Information Office, Cooperative Extension Service, Institute of Food and Agricultural Sciences, University of Florida, Gainesville, FL.

The Institute of Food and Agricultural Sciences (IFAS) is an Equal Opportunity Institution authorized to provide research, educational information and other services only to individuals and institutions that function with non-discrimination with respect to race, creed, color, religion, age, disability, sex, sexual orientation, marital status, national origin, political opinions or affiliations. U.S. Department of Agriculture, Cooperative Extension Service, University of Florida, IFAS, Florida A. \& M. University Cooperative Extension Program, and Boards of County Commissioners Cooperating. Interim Dean Millie Ferrer. 
Construct a berm or bank between the application site and surface-water bodies to prevent or reduce the amount of water running off the field into the surface water following a heavy rainfall. Develop a buffer zone, such as a grass border, between the field or the site used for pesticide mixing and loading and surface-water-sensitive areas (Figure 2). Water should pass through a grass "filter" strip when draining off fields into canals or other water conveyances.

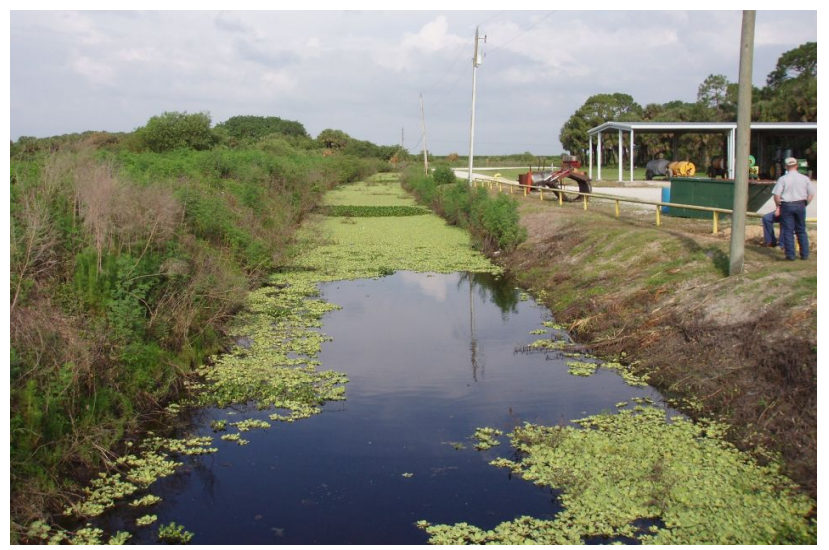

Figure 2. Grass and weeds provide a filter strip between a citrus grove and mixing site and canal.

\section{Evaluate the Pesticide/Follow the Label}

Select pesticides that are less likely to leach. Pesticides that have the greatest potential to leach to groundwater are highly water soluble, relatively persistent and do not adsorb to soil. Some pesticides are classified as restricted use and have label statements because of concerns over water contamination (Figure 3). Read the label before you purchase, use, or dispose of a pesticide. You are required by law to follow label directions. Be aware that there are several Florida-specific laws that place limitations on use of certain pesticides, including aldicarb and bromacil. Label language will alert users of such limitations. The Cooperative Extension Service can assist you in selecting the appropriate pesticide. For your local county extension office, see http://solutionsforyourlife.ufl.edu/map/index.html.
RESTRICTED USE PESTICIDE DUE TO GROUND AND SURFACE WATER CONCERNS
For retail sale to and use only by certified applicators or persons under their direct supervision, and only for those
uses covered by the certified applicator's certfifation. This product is a restricted use herbicide due to ground and surface water concerns. Users must read and follow
all precautionary statements and instructions for use in order to minimize potential for atrazine to reach ground all precautionary
and surface wate

Figure 3. Restricted-use pesticide classification due to concerns over protecting groundwater and surface water. Credits: CDMS.

\section{Evaluate Location of Water Sources}

Pesticide contamination of water frequently is associated with pesticide-handling practices in the vicinity of wells and other water sources. Pesticide spills near wells can move directly and quickly into groundwater. Wells should be properly cased, capped, and grouted.

Unprotected wells act as conduits for surface contaminants to the aquifer. Open wells near sites used for mixing or loading pesticides are particularly vulnerable to contamination. Slope the grade around the wellhead to direct runoff away from the well. Close abandoned wells and never dispose of wastes in unused wells. Avoid mixing, storing, or disposing of pesticides within 100 feet of a well. Some pesticide labels may recommend specific distances that pesticides should not be mixed and loaded within various surface-water bodies, such as intermittent streams and rivers, natural or impounded lakes, and reservoirs.

\section{Use Integrated Pest Management (IPM)}

The practice of IPM combines chemical, cultural, and biological control into one program to manage pest populations. Fields must be scouted to identify pests, their population levels, and extent of damage. Make pesticide applications only when necessary, using the lowest rate required for adequate control. Reduction in the amount of pesticide use lowers potential movement of pesticides to sources of water, protects the natural environment and reduces costs. For more information on IPM programs and practices contact your IFAS Cooperative Extension Service county office (http://solutionsforyourlife.ufl.edu/map/\#county). 


\section{Consider Weather and Irrigation}

Delay the pesticide application if heavy or sustained rain is anticipated. Pesticide runoff and leaching are favored by rainfall soon after application. Do not apply pesticides before scheduled irrigations unless the product must be activated by moisture. Control the quantity of irrigation water to minimize leaching and runoff.

\section{Measure Pesticides Carefully}

Accurately calculate the amount of pesticide needed to treat the site to assure you are staying within the label rate. Careful calculations help eliminate disposal problems associated with excess spray mix.

\section{Calibrate Sprayer}

Calibrate application equipment frequently to assure the desired amount of pesticide is being applied (Figure 4). Check the equipment for leaks and malfunctions.

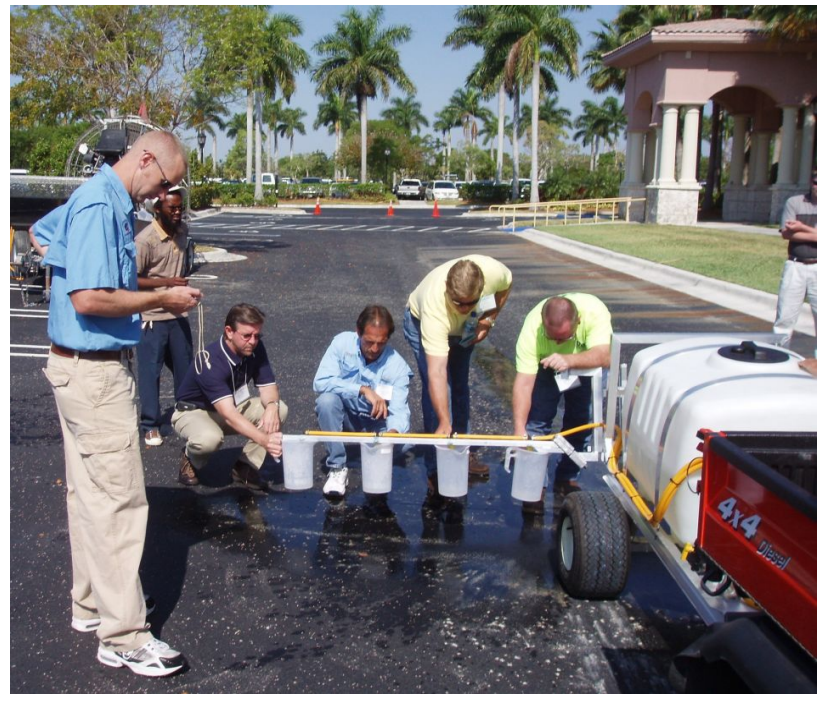

Figure 4. Checking a sprayer's output to determine the amount applied. Credits: F.M. Fishel, UF/IFAS PIO.

\section{Mix and Load Carefully}

Repeated pesticide spills at mixing and loading sites may exceed the capacity of the soil to adsorb or degrade the chemical, increasing the likelihood of groundwater contamination. If spills occur, follow containment and cleanup procedures. Consult the label or the County Extension office for cleanup procedures.
If possible, mix and load on a permanent or portable containment pad to avoid saturating the soil with pesticide (Figure 5). If the water source (well, canal or pond) used for filling a spray tank is not protected by a concrete pad, berm or wall to prevent runoff into the source, fill the spray tank as far as possible from the water source or fill the tank in the field from a nurse tank. Nurse tanks are used to transport clean water for mixing and loading. Add the pesticide concentrate to the sprayer in the field.

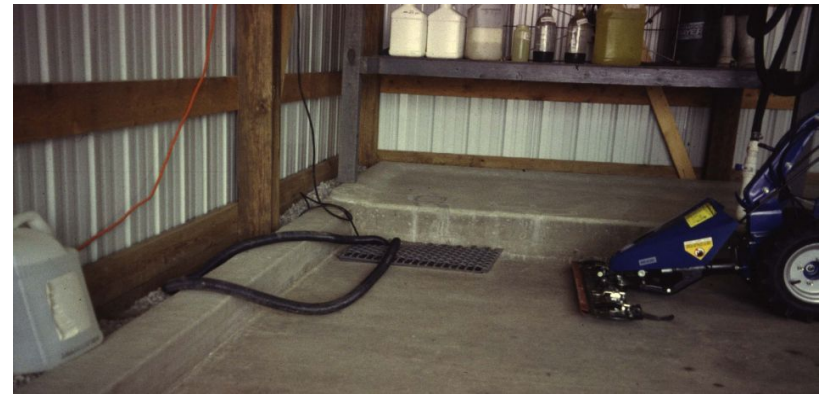

Figure 5. Permanent concrete mixing and loading area with diked edging for containment. Credits: F.M. Fishel, UF/IFAS PIO.

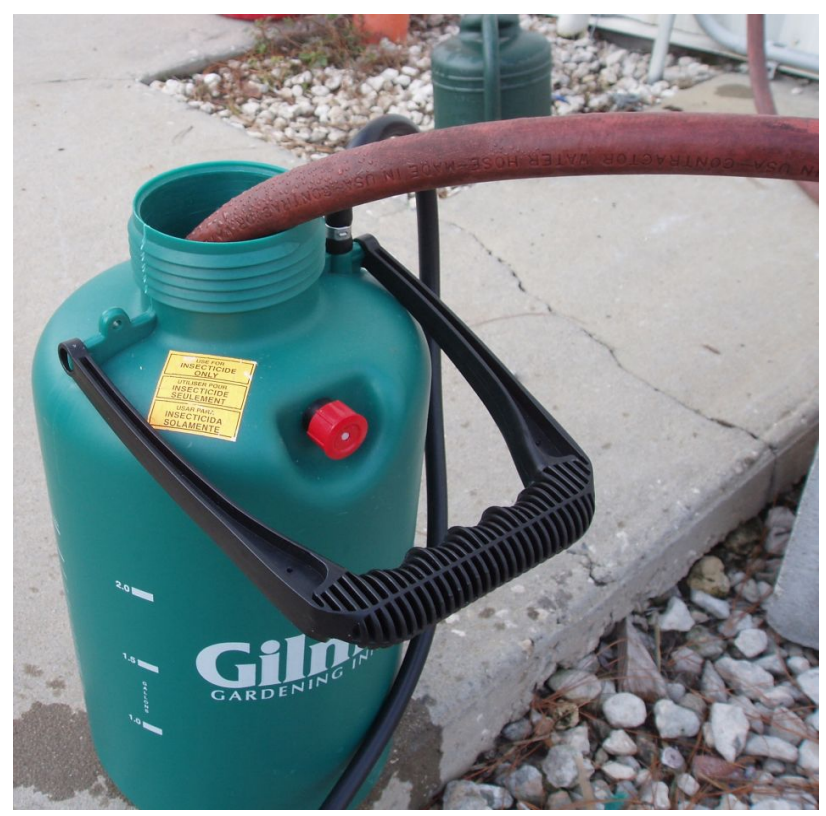

Figure 6. Never place a hose into a tank while filling; always leave an air gap to prevent back-siphoning. Credits: F.M. Fishel, UF/IFAS PIO.

Use a check valve (anti-siphon device) or an air gap between the end of the water supply hose and the highest water level in the spray tank to prevent back-siphoning from the spray tank into the water supply (Figure 6). Anti-siphon devices are required for chemigation equipment in Florida. Do not leave 
the spray tank unattended when filling. Do not allow tanks to drain at mixing and loading sites. Close the tank opening to prevent spills when transporting the sprayer to the field.

\section{Store Pesticides Safely}

Store pesticides in a facility with restricted access and away from all water resources. Use a facility with a concrete floor that has been sealed to facilitate clean-up in the event of a spill or leak. Inspect containers regularly for leaks and corrosion. Bulk pesticide storage tanks should be placed on concrete pads with dikes built around the tanks to prevent movement of pesticide should a spill or leak occur (Figure 7).

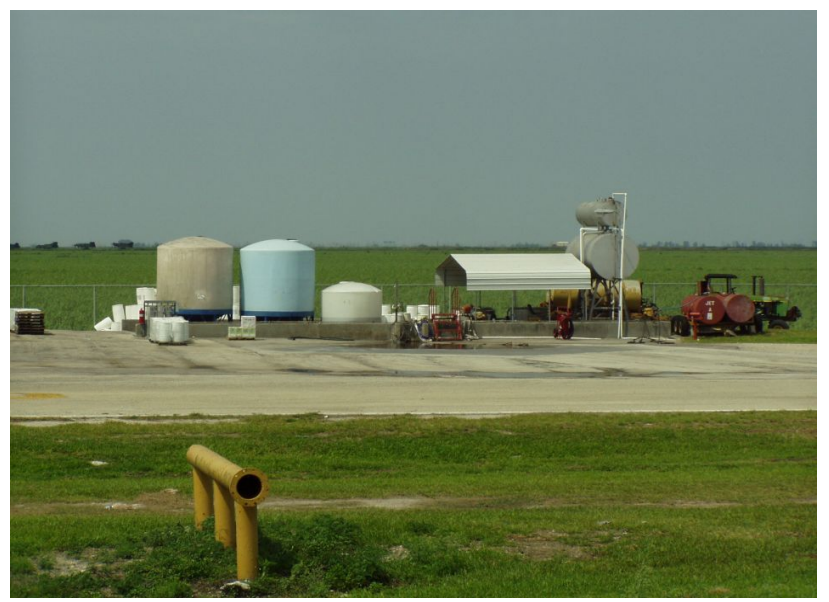

Figure 7. Bulk storage tanks on diked-concrete pad. Credits: F.M. Fishel, UF/IFAS PIO.

\section{Dispose of Wastes Carefully}

Follow the label when disposing of pesticides. Triple or pressure rinse empty pesticide containers and add the rinse to the spray tank. Apply excess spray mix and rinse water from equipment cleaning to crops or sites listed on the label. Don't drain the excess on the ground. Mount a tank of fresh water on the sprayer to rinse the tank and sprayer. Where practical, excess spray mix or rinses can be held in a tank for use in a later spray mix (Figure 8).

Take empty, rinsed plastic pesticide containers to pesticide container recycling facilities or to sanitary landfills. Excess pesticide concentrates can be given to another qualified user, safely stored for hazardous-waste-collection days, or disposed of by a firm licensed to dispose of hazardous waste.

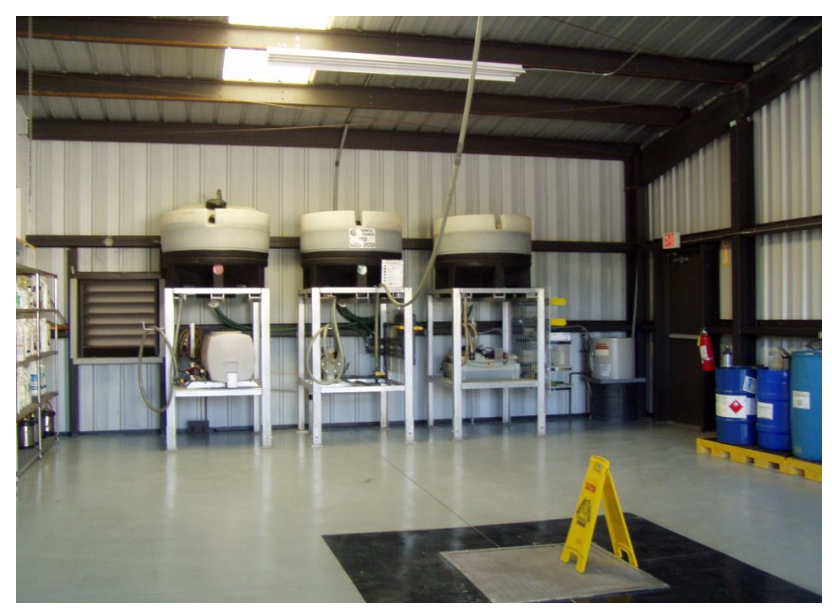

Figure 8. Bulk storage tanks holding spray mix and rinse for later use. Credits: F.M. Fishel, UF/IFAS PIO.

\section{References}

Some of the information in this Fact Sheet was adapted from the following sources:

The Fate of Pesticides in the Environment and Groundwater Protection, Agrochemical Fact Sheet 8, College of Agriculture, Cooperative Extension, Pennsylvania State Univ. 1989.

Farm Chemicals--A Blueprint for Protecting Groundwater, Meister Publishing Co., Willoughby, OH. Special Issue: Summer, 1989.

Fishel, F.M. 2005. Specifically Regulated Pesticides in Florida - Aldicarb. EDIS Publication PI-74, http://edis.ifas.ufl.edu/document_pi111 (accessed March, 2009). Agronomy Department, Cooperative Extension Service, University of Florida, Gainesville, Florida.

Fishel, F.M. 2005. Specifically Regulated Pesticides in Florida - Bromacil. EDIS Publication PI-75, http://edis.ifas.ufl.edu/document_pi112 (accessed March, 2009). Agronomy Department, Cooperative Extension Service, University of Florida, Gainesville, Florida. 
Obreza, T.A. and G.W. Hurt. 2006. Soil Ratings

for Selecting Pesticides for Water Quality Goals.

EDIS Circular 959,

http://edis.ifas.ufl.edu/document_ss056 (accessed

March, 2009). Soil and Water Science Department,

Cooperative Extension Service, University of

Florida, Gainesville, Florida.

Obreza, T.A. and M.E. Collins. 2002. Common

Soils Used for Citrus Production in Florida, EDIS

Circular SL 193,

http://edis.ifas.ufl.edu/document_ss403 (accessed

March, 2009). Soil and Water Science Department,

Cooperative Extension Service, University of

Florida, Gainesville, Florida. 